\title{
PATTERN RECOGNITION: PHYSICAL EXERCISES MODES DURING MOTOR SKILLS DEVELOPMENT IN GIRLS AGED 14
}

\author{
Kapkan O.O. ${ }^{1}$, Khudolii O.M. ${ }^{2}$, Bartík P. ${ }^{3}$ \\ ${ }^{1}$ Donbas National Academy of Civil Engineering and Architecture \\ ${ }^{2}$ H.S. Skovoroda Kharkiv National Pedagogical University \\ ${ }^{3}$ Matej Bel University
}

Corresponding Author: Kapkan O.O., e-mail: ekapkan@gmail.com

Accepted for Publication: December 20, 2018

Published: December 25, 2018

DOI:10.17309/tmfv.2018.4.02

\begin{abstract}
The study objective is to determine physical exercises modes when developing motor skills in girls aged 14 . Materials and methods. The participants in the study were 40 girls aged 14 . To achieve the objective set, the following research methods were used: study and analysis of scientific and methodological literature; pedagogical observation, timing of training tasks; pedagogical experiment, methods of mathematical statistics, methods of mathematical experiment planning, discriminant analysis.

Results. The first canonical function explains $73.3 \%$ of the variation in results, the second function $-21.6 \%$, which indicates their high informativity $\left(r_{1}=0.898 ; r_{2}=0.743\right)$. The analysis of canonical functions highlights the statistical significance of the first and second canonical functions $\left(\lambda_{1}=.067 ; p_{1}=0.001\right.$; $\left.\lambda_{2}=0.346 ; p_{2}=0.001\right)$. The first and second functions have a high discriminative ability and value of interpretation with respect to the general totality. The number of repetitions for mastering the first and fourth series of training tasks has the largest contribution to the first canonical function. This indicates that the exercises for developing motor abilities and teaching to control movement time and muscular effort influence the effectiveness of teaching a press headstand and handstand. The number of repetitions for mastering the second and third series of training tasks has the largest contribution to the second canonical function. This indicates that starting and ending positions, and actions without which the exercise performance is impossible influence the effectiveness of teaching a press headstand and handstand.

Conclusions. The discriminant function structure coefficients show that the training program effectiveness is determined by selecting the series of training tasks and their performance modes. To choose the most rational mode of exercises of the series of tasks when teaching girls aged 14 a press headstand and handstand, the first discriminant function can be used with an emphasis on the most informative variables.

Keywords: discriminant analysis, series of training tasks, programmed learning, girls.
\end{abstract}

\section{Introduction}

The analysis of scientific and methodological literature highlights the relevance of focusing attention on the study of regularities of motor skills development in children and adolescents (Wright, 1999; Khudolii \& Ivashchenko, 2014; Rink, Jones, Kirby, Mitchell \& Doutis, 2007).

In their research papers, Khudolii and Ivashchenko (2014), Lopatiev, Ivashchenko, Khudolii, Pjanylo, Chernenko and Yermakova (2017) substantiated the conceptual approaches to experiment planning when studying the effectiveness of learning process and developing learning models. The researchers ascertained the effectiveness of using factorial plans when studying

(C) Kapkan O.O., Khudolii O.M., Bartík P., 2018. the process of teaching children and adolescents and developing regression models. The papers by Acher, Arca and Sanmarti (2007), Chatzipanteli, Digelidis, Karatzoglidis and Dean (2016) point to the importance of modeling process in children's cognitive activity.

In their papers, Chernenko (2015), Ivashchenko, Iermakov, Khudolii, Yermakova, Cieślicka and Harkusha (2018), Ivashchenko (2017) reveal that the learning process effectiveness can be improved by analyzing regression models and calculating optimal modes of physical exercises during physical education classes.

According to Samuel, Zavdy, Levav, Reuveny, Katz and Dubnov-Raz (2017), Balaban (2018), physical activity can both positively and negatively effect children's cognitive activity and their motor skills development. 
However, there has been little research on physical exercises modes when mastering the series of training tasks within programmed learning.

Thus, it is relevant to classify physical exercises modes in the process of mastering training tasks by middle school students.

The study objective is to determine physical exercises modes when developing motor skills in girls aged 14 .

\section{Materials and methods}

Study participants. The participants in the study were 40 girls aged 14 . The children and their parents were fully informed about all the features of the study and agreed to participate in the experiment.
Study organization. To achieve the objective set, the following research methods were used: study and analysis of scientific and methodological literature; pedagogical observation, timing of training tasks; pedagogical experiment, methods of mathematical statistics, methods of mathematical experiment planning, discriminant analysis.

The pedagogical experiment was conducted in the secondary school No. 22, Kramatorsk, Donetsk region, in the 2012-2013, 2013-2014 academic years.

During the learning process, the study used a method of algorithmic orders. The press headstand and handstand training program included training tasks given in Table 1 . The student could proceed to the next

Table 1. Press headstand and handstand training program

\begin{tabular}{ccc}
\hline $\begin{array}{c}\text { Informative frame } \\
\text { (what is performed) }\end{array}$ & $\begin{array}{c}\text { Operational frame } \\
\text { (how it is performed) }\end{array}$ & $\begin{array}{c}\text { Control frame } \\
\text { (proceed to training the next exercise) }\end{array}$ \\
\hline
\end{tabular}

First series of training tasks - exercises for developing motor abilities

From stoop standing position, with the back Performed by jumping off both feet, hold If the student performs the exercise against stall bars, proceed to arch hang the position for 3-4 seconds correctly three times in a row, proceed to the next exercise

In prone position, bend arms and knees (5 Performed with maximum amplitude times in 5-6 seconds)

If the student performs the exercise for 5-6 seconds, proceed to the next exercise

Second series of training tasks - starting and ending positions

From squatting position, lean forward, put the Hold the position for 3-4 seconds $\quad$ If the student performs the exercise head down on mat on the marking and evenly shift the body weight to the head and arms correctly three times in a row, proceed to the next exercise

Third series of training tasks - actions without which the exercise performance is impossible

From squatting position, return to starting Transition to headstand and handstand If the student performs the exercise position to perform a headstand and should be done by straightening the legs correctly three times in a row, proceed to handstand. Straighten the legs, transition to a headstand and handstand with bent legs the next exercise

Fourth series of training tasks - teaching to control movement time and muscular effort

Inkneeling position, bending and straightening Bend the arms simultaneously with If the student performs the exercise for 5-6 of the arms (5 times)

Bending and straightening of the arms in stoop standing position (5 times) straightening the legs. Perform in 5 seconds, proceed to the next exercise seconds

From normal standing position, lean forward, Do not bend knees when performing the If the student performs the exercise for 5-6 touch the floor with the palms and, walking exersise. Perform in 6 seconds

slowly on the hands, adopt a prone position

and return to starting position in the same way

Fifth series of training tasks - separate parts of the target exercise and preliminary exercises

From squatting position, return to starting Straighten the back and hold balance with If the student performs the exercise position to perform a headstand and bent legs for 3-4 seconds

handstand. Straighten the legs, transition to a correctly three times in a row, proceed to the next exercise

headstand and handstand with bent legs

Perform a headstand and handstand, back and Focus on the exercise technique

legs against the wall, with assistance

If the student performs the exercise correctly three times in a row, proceed to the next exercise

Sixth series of training tasks - performing the whole exercise

Perform a headstand and handstand, back and Hold the headstand and handstand for 3-4 If the student performs the exercise legs against the wall, without assistance seconds correctly three times in a row, proceed to the next exercise

Headstand and handstand without assistance

Hold the headstand and handstand for 3-4 Correct performance of the series at the seconds third attempt 
exercise only after a correct performance of the previous exercise on three consecutive attempts. The number of repetitions needed to teach exercises in each series of training tasks were recorded. The level of proficiency in the physical exercises performance was determined by the alternative method: "performed" or "failed". A technically correct performance of the exercise gave the students " 1 " point; a failure to perform the exercise gave them " 0 " entered in the protocol.

To achieve the objective set, the study examined the effect of different variants of exercises, specifically: the number of repetitions $\left(x_{1}\right)$ and rest intervals $\left(x_{2}\right)$ on mastering a press headstand technique. The girls aged 14 were divided into four groups according to the experiment plan. The differences between the groups in the lesson plan resulted from the factorial experiment conditions presented in Table 2. The bottom and top levels of the factors were chosen based on the data provided by Khudolii and Ivashchenko (2014), Ivashchenko (2016), Chernenko (2015), and were limited to the lesson framework.

Statistical analysis. This paper used the methods of analyzing the results of mathematical experiment planning of a $2 \kappa$ type full factorial experiment (Khudolii \& Ivashchenko, 2014; Ivashchenko, 2016).

The study materials were processed by the IBM SPSS 20 statistical analysis software. In the process of

Table 2. $2^{2}$ type factorial experiment plan

\begin{tabular}{ccc}
\hline Variants of & \multicolumn{2}{c}{ Modes of training } \\
\cline { 2 - 3 } exercises & Repetition number & Rest interval \\
\hline 1 & $6-$ & $60-$ \\
2 & $12+$ & $60-$ \\
3 & $6-$ & $120+$ \\
4 & $12+$ & $120+$ \\
\hline
\end{tabular}

discriminant analysis, the study created a prognostic model for group membership. This model develops a discriminant function (or, when there are more than two groups - a set of discriminant functions) in the form of a linear combination of predictor variables, ensuring the best division of groups. These functions are developed according to a set of observations, for which their group membership is known. These functions can continue to be used for new observations with known values of predictor variables and unknown group membership.

For each canonical discriminant function, the study calculated: eigenvalue, dispersion percentage, canonical correlation, Wilks' Lambda, Chi-square.

The study protocol was approved by the Ethical Committee of the University. In addition, the children and their parents or legal guardians were fully informed about all the features of the study, and a signed informedconsent document was obtained from all the parents.

\section{Study results}

Table 3 shows the results of discriminant analysis, which speak to the influence of different modes of physical exercises on the effectiveness of mastering the series of training tasks of acrobatic exercises by the girls aged 14. Statistically significant differences in the number of repetitions needed to master the exercises are observed in the first, second, fourth, fifth, and sixth series of training tasks. The proposed modes of physical exercises have no statistically significant influence $(p>0.05)$ on mastering the third series of training tasks (actions without which the exercise performance is impossible).

To master the first, second, and sixth series of training tasks, the best option is the first mode of physical exercises: 6 repetitions with a rest interval of 60 seconds.

To clarify the effect of different modes of physical exercises on the level of proficiency, the study conducted a discriminant analysis (see Table 3-9).

The first canonical function explains $73.3 \%$ of the variation in results, the second function $-21.6 \%$, which indicates their high informativity $\left(r_{1}=0.898\right.$; $r_{2}=0.743$ ) (see Table 4). The materials of the canonical functions analysis show the statistical significance of the first and second canonical functions $\left(\lambda_{1}=.067 ; p_{1}=0.001\right.$; $\left.\lambda_{2}=0.346 ; p_{2}=0.001\right)$. The first and second functions have a high discriminative ability and value of interpretation with respect to the general totality (Table 5).

Table 6 presents standardized coefficients of the canonical discriminant function, which make it possible to determine the ratio of variables' contribution to the function result.

The number of repetitions for mastering the first and fourth series of training tasks has the largest contribution to the first canonical function. This indicates that the exercises for developing motor abilities and teaching to control movement time and muscular effort influence the effectiveness of teaching a press headstand and handstand. The number of repetitions for mastering the second and third series of training tasks has the largest contribution to the second canonical function. This indicates that the starting and ending positions, and actions without which the exercise performance is impossible influence the effectiveness of teaching a press headstand and handstand.

Table 7 presents structure coefficients of the first canonical discriminant function, which are the coefficients of correlation between the variables and the function. The function is most substantially related to the results of mastering the first and sixth series of training tasks: thus, a significant difference between modes of exercises 1-4 is observed in the number of repetitions needed to develop motor abilities and to master the whole exercise. The structure coefficients of the second canonical discriminant function show that the function is most substantially related to the results 
Table 3. $2^{2}$ full factorial experiment analysis results. Girls aged 14

\begin{tabular}{|c|c|c|c|c|c|c|}
\hline Series of training tasks & Variant & $\begin{array}{c}\text { Mean. } \\
\text { Repetition } \\
\text { number }\end{array}$ & Std. Deviation & $\begin{array}{c}\text { Wilks' } \\
\text { Lambda }\end{array}$ & $\mathbf{F}$ & $\mathbf{p}$ \\
\hline \multicolumn{7}{|c|}{ First series of training tasks - exercises for developing motor abilities } \\
\hline First series of training tasks & 1 & 9.2 & 2.57 & \multirow{4}{*}{.405} & \multirow{4}{*}{17.603} & \multirow{4}{*}{.001} \\
\hline First series of training tasks & 2 & 13.4 & 1.71 & & & \\
\hline First series of training tasks & 3 & 16.1 & 2.81 & & & \\
\hline First series of training tasks & 4 & 15.5 & 2.17 & & & \\
\hline \multicolumn{7}{|c|}{ Second series of training tasks - starting and ending positions } \\
\hline Second series of training tasks & 1 & 7.6 & .97 & \multirow{4}{*}{.436} & \multirow{4}{*}{15.534} & \multirow{4}{*}{.001} \\
\hline Second series of training tasks & 2 & 11.0 & 1.05 & & & \\
\hline Second series of training tasks & 3 & 9.8 & 1.23 & & & \\
\hline Second series of training tasks & 4 & 9.3 & 1.25 & & & \\
\hline \multicolumn{7}{|c|}{$\begin{array}{l}\text { Third series of training tasks - actions without which the exercise performance is impossible } \\
\text { Therm }\end{array}$} \\
\hline Third series of training tasks & 1 & 13.3 & 1.57 & \multirow{4}{*}{.825} & \multirow{4}{*}{2.543} & \multirow{4}{*}{.072} \\
\hline Third series of training tasks & 2 & 16.1 & 2.81 & & & \\
\hline Third series of training tasks & 3 & 14.6 & 2.88 & & & \\
\hline Third series of training tasks & 4 & 15.5 & 2.17 & & & \\
\hline \multicolumn{7}{|c|}{ Fourth series of training tasks - teaching to control movement time and muscular effort } \\
\hline Fourth series of training tasks & 1 & 15.4 & 2.17 & \multirow{4}{*}{.578} & \multirow{4}{*}{8.768} & \multirow{4}{*}{.001} \\
\hline Fourth series of training tasks & 2 & 14.2 & 2.62 & & & \\
\hline Fourth series of training tasks & 3 & 10.5 & 2.42 & & & \\
\hline Fourth series of training tasks & 4 & 13.3 & 1.57 & & & \\
\hline \multicolumn{7}{|c|}{ Fifth series of training tasks - separate parts of the target exercise and preliminary exercises } \\
\hline Fifth series of training tasks & 1 & 12.0 & 3.16 & \multirow{4}{*}{.807} & \multirow{4}{*}{2.877} & \multirow{4}{*}{.049} \\
\hline Fifth series of training tasks & 2 & 14.4 & 2.95 & & & \\
\hline Fifth series of training tasks & 3 & 14.4 & 2.95 & & & \\
\hline Fifth series of training tasks & 4 & 11.1 & 3.48 & & & \\
\hline \multicolumn{7}{|c|}{ Sixth series of training tasks - performing the whole exercise } \\
\hline Sixth series of training tasks & 1 & 5.9 & .74 & \multirow{4}{*}{.486} & \multirow{4}{*}{12.673} & \multirow{4}{*}{.001} \\
\hline Sixth series of training tasks & 2 & 8.7 & 1.89 & & & \\
\hline Sixth series of training tasks & 3 & 10.2 & 1.81 & & & \\
\hline Sixth series of training tasks & 4 & 8.6 & 1.65 & & & \\
\hline
\end{tabular}

Table 4. Eigenvalues. Girls aged 14

\begin{tabular}{lcccc}
\hline Function & Eigenvalue & $\begin{array}{c}\% \text { of } \\
\text { Variance }\end{array}$ & $\begin{array}{c}\text { Cumulative } \\
\%\end{array}$ & $\begin{array}{c}\text { Canonical } \\
\text { Correlation }\end{array}$ \\
\hline 1 & 4.183 & 73.3 & 73.3 & .898 \\
2 & 1.233 & 21.6 & 94.8 & .743 \\
3 & .294 & 5.2 & 100.0 & .477 \\
\hline
\end{tabular}

Table 5. Wilks' Lambda. Girls aged 14

\begin{tabular}{lcccc}
\hline $\begin{array}{c}\text { Test of } \\
\text { Function(s) }\end{array}$ & $\begin{array}{c}\text { Wilks' } \\
\text { Lambda }\end{array}$ & Chi-square & df & Sig. \\
\hline 1 through 3 & .067 & 92.033 & 18 & .000 \\
2 through 3 & .346 & 36.087 & 10 & .000 \\
3 & .773 & 8.771 & 4 & .067 \\
\hline
\end{tabular}

Table 6. Standardized canonical discriminant function coefficients. Girls aged 14

\begin{tabular}{llcl}
\hline \multirow{2}{*}{\multicolumn{1}{c}{ Series of training tasks }} & \multicolumn{3}{c}{ Function } \\
\cline { 2 - 4 } & $\mathbf{1}$ & $\mathbf{2}$ & $\mathbf{3}$ \\
\hline First series of training tasks & .846 & -.497 & .427 \\
Second series of training tasks & .229 & .982 & .123 \\
Third series of training tasks & -.110 & .647 & .207 \\
Fourth series of training tasks & -.722 & .085 & .360 \\
Fifth series of training tasks & -.045 & .294 & -.785 \\
Sixth series of training tasks & .338 & -.310 & -.203 \\
\hline
\end{tabular}

Table 7. Structure matrix. Girls aged 14

\begin{tabular}{lccc}
\hline \multirow{2}{*}{\multicolumn{1}{c}{ Series of training tasks }} & \multicolumn{3}{c}{ Function } \\
\cline { 2 - 4 } & $\mathbf{1}$ & $\mathbf{2}$ & $\mathbf{3}$ \\
\hline First series of training tasks & $.579^{\star}$ & -.027 & .465 \\
Sixth series of training tasks & $.496^{\star}$ & .123 & -.171 \\
Second series of training tasks & .369 & $.766^{\star}$ & .072 \\
Fifth series of training tasks & .102 & .244 & $-.646^{\star}$ \\
Fourth series of training tasks & -.382 & .210 & $.467^{\star}$ \\
Third series of training tasks & .126 & .282 & $.399^{\star}$ \\
\hline
\end{tabular}

of mastering the second series of training tasks: thus, a significant difference between modes of exercises 2-4 is observed in the number of repetitions needed to master the starting and ending positions of the exercises.

Table 8 shows the classification results of the groups, $85.0 \%$ of the original grouped observations were classified correctly. Therefore, the canonical discriminant function can be used to classify the modes of physical exercises during motor skills development.

Table 9 presents the centroid coordinates for the three groups. They make it possible to interpret the canonical function in relation to the classification role. The graphic material given in Fig. 1 shows the density of 
Table 8. Classification resultsa

\begin{tabular}{|c|c|c|c|c|c|c|c|}
\hline & \multirow[t]{2}{*}{ Scale } & \multirow{2}{*}{$\begin{array}{l}\text { Modes of } \\
\text { exercises }\end{array}$} & \multicolumn{4}{|c|}{$\begin{array}{l}\text { Predicted group } \\
\text { membership }\end{array}$} & \multirow[t]{2}{*}{ Total } \\
\hline & & & 1 & 2 & 3 & 4 & \\
\hline \multirow{8}{*}{ 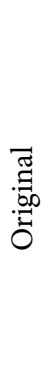 } & \multirow{4}{*}{ Count } & 1 & 10 & 0 & 0 & 0 & 10 \\
\hline & & 2 & 1 & 8 & 0 & 1 & 10 \\
\hline & & 3 & 0 & 0 & 7 & 3 & 10 \\
\hline & & 4 & 0 & 0 & 1 & 9 & 10 \\
\hline & \multirow{4}{*}{$\%$} & 1 & 100.0 & .0 & .0 & .0 & 100.0 \\
\hline & & 2 & 10.0 & 80.0 & .0 & 10.0 & 100.0 \\
\hline & & 3 & .0 & .0 & 70.0 & 30.0 & 100.0 \\
\hline & & 4 & .0 & .0 & 10.0 & 90.0 & 100.0 \\
\hline
\end{tabular}

Table 9. Functions at group centroids. Unstandardized canonical discriminant functions evaluated at group means

\begin{tabular}{lcccc}
\hline & $\begin{array}{c}\text { Modes of } \\
\text { exercises }\end{array}$ & $\mathbf{1}$ & $\mathbf{2}$ & $\mathbf{3}$ \\
\cline { 2 - 5 } & -3.034 & -.622 & -.234 \\
1 & -.012 & 1.824 & -.015 \\
2 & 2.302 & -.623 & -.574 \\
3 & .744 & -.579 & .822 \\
4 & & & & \\
\hline
\end{tabular}

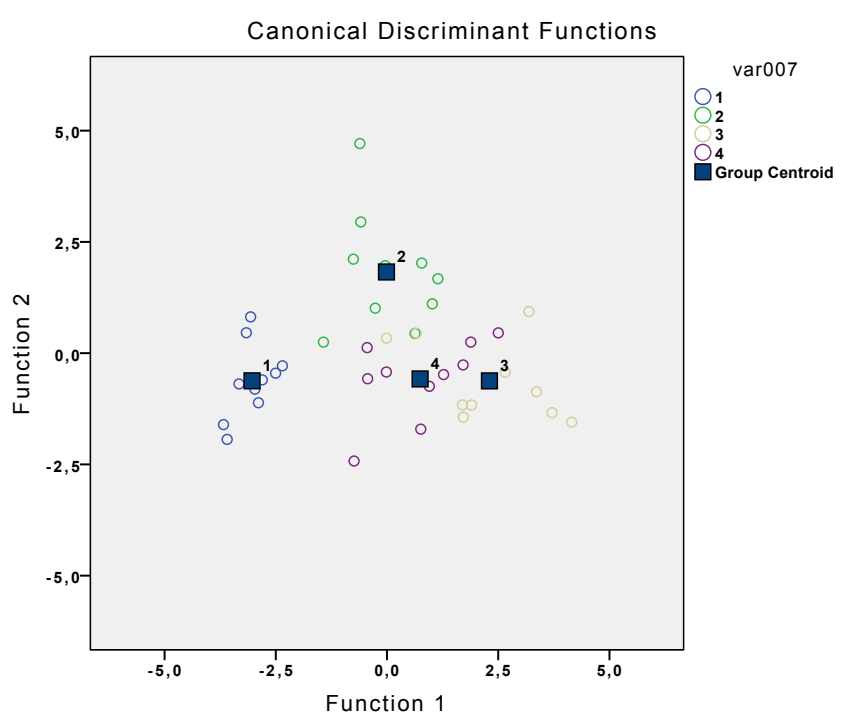

Fig. 1. Graphic representation of the classification results (modes of physical exercises 1-4)

objects in each class and the distinct boundary between the classes. The most effective mode of physical exercises when teaching the series of tasks is the first one.

\section{Discussion}

The paper assumed that a full factorial experiment and discriminant analysis would make it possible to determine the peculiarities of developing motor skills in girls aged 14 . The study results show that in the suggested matrix of factorial experiment plan, the chosen step of variation of factors is sufficient to study the influence of different physical exercises modes on the effectiveness of teaching a press headstand and handstand (Table 2).

The study makes an assumption on the possibility of using a discriminant function to evaluate the effectiveness of different modes of physical exercises when teaching the series of tasks. The verification of the canonical functions shows their statistical significance, and the discriminant function equation provides a possibility to select the best option for obtaining a positive effect when teaching the series of exercises (Table 10). The best option for teaching the girls aged 14 the headstand and handstand series of tasks is the first mode of physical exercises: 6 repetitions with a rest interval of 60 seconds.

Table 10. Canonical discriminant function coefficients. Unstandardized coefficients

\begin{tabular}{lccc}
\hline \multirow{2}{*}{\multicolumn{1}{c}{ Series of training tasks }} & \multicolumn{3}{c}{ Function } \\
\cline { 2 - 4 } & $\mathbf{1}$ & $\mathbf{2}$ & $\mathbf{3}$ \\
\hline First series of training tasks & .360 & -.211 & .181 \\
Second series of training tasks & .203 & .868 & .108 \\
Third series of training tasks & -.046 & .268 & .086 \\
Fourth series of training tasks & -.324 & .038 & .162 \\
Fifth series of training tasks & -.014 & .094 & -.250 \\
Sixth series of training tasks & .213 & -.195 & -.127 \\
(Constant) & -3.368 & -9.394 & -2.607 \\
\hline
\end{tabular}

The study results supplement the data obtained by Khudolii and Ivashchenko (2014), Kapkan (2015), Ivashchenko (2016) on the effectiveness of using factorial experiment plans when studying the effectiveness of children and adolescents' learning process.

According to García-Moya, Moreno and JiménezIglesias (2012), Wang, Karns and Meredith (2003), the use of factorial experiment plans in studies involving adolescents and children improves the quality of evaluating their development indicators. The data obtained by Correa et al. $(2009,2012)$ confirm the validity of using a $2^{\mathrm{k}}$ type full factorial experiment.

The obtained results:

- specify the conceptual approaches to experiment planning when studying the effectiveness of learning process and developing learning models for children (Khudolii \& Iermakov, 2011; Ivashchenko, 2016);

- supplement the information on the use of a discriminant function when classifying schoolchildren by motor skills development (Cantell, Smyth \& Ahonen, 2003) and their attitude towards physical education and out-ofschool physical activity (Donovan, Mercier \& Phillips, 2015);

- confirm the data on the effectiveness of using a discriminant function when studying the effect 
of physical activity on motor skills development in children (Ivashchenko, 2016; Herrmann, Gerlach, \& Seelig, 2016).

The prospect for further exploration is to study the regularities of teaching physical exercises to boys aged 14-15.

\section{Conclusions}

The $2^{2}$ type experiment made it possible to study the multifactorial structure of teaching the girls aged 14 , using a program of algorithmic orders, to specify the optimal correlations of factors for their use when teaching physical exercises during physical education classes.

The discriminant analysis made it possible to determine the modes of physical exercises during motor skills development; to answer the question as to the significance of difference between the modes of work by the effectiveness of motor skills development; to define what motor tests most substantially influence the differentiation of classes; what class the object belongs to based on the values of discriminant variables. The discriminant function structure coefficients show that the training program effectiveness is determined by selecting the series of training tasks and modes of their performance.

To choose the most rational mode of exercises of the series of tasks when teaching girls aged 14 a press headstand and handstand, the first discriminant function can be used with an emphasis on the most informative variables.

\section{Acknowledgement}

The study was carried out in accordance with the research plan of the Ministry of Education and Science, Youth and Sports of Ukraine, within the topic 13.04 "Modeling of teaching and motor abilities development in children and adolescents" (2013-2014) (state registration number: 0113U002102).

\section{Conflict of interest}

The author declares no conflict of interests.

\section{References}

Khudolii, O.M., \& Ivashchenko, O.V. (2014). Simulation of the learning process and development of motor abilities in children and adolescents: Monograph. Kharkiv : OVS, 320. (in Ukrainian)

Lopatiev, A., Ivashchenko, O., Khudolii, O., Pjanylo, Y., Chernenko, S., \& Yermakova T. (2017). Systemic approach and mathematical modeling in physical education and sports. Journal of Physical Education and Sport (JPES), 17(1), suplement, 146-155. https://doi.org/10.7752/jpes.2017.s1023

Ivashchenko, O., Iermakov, S., Khudolii, O., Yermakova, T., Cieślicka, M., \& Harkusha, S. (2018). Simulation of the regularities of physical exercises learning process of boys aged 8 years old. Pedagogics, Psychology, Medical-Biological Problems of Physical Training and Sports, 22(1), 11-16.

https://doi.org/10.15561/18189172.2018.0102

Judith Rink, Laura Jones, Kym Kirby, Murray Mitchell, \& Panayiotis Doutis(2007). Teacher Perceptions of a Physical Education Statewide Assessment Program. Research Quarterly for Exercise and Sport, 78(3), 204215. https://doi.org/10.1080/02701367.2007.10599418

Balaban, V. (2018). The relationship between objectively measured physical activity and fundamental motor skills in 8 to 11 years old children from the Czech Republic. Montenegrin Journal of Sports Science and Medicine, 7(2), 11-16.

https://doi.org/10.26773/mjssm.180902

Ivashchenko, O. (2017). Classification of 11-13 yrs girls' motor fitness, considering level of physical exercises' mastering. Pedagogics, Psychology, Medical-Biological Problems of Physical Training and Sports, 21(2), 65-70. https://doi.org/10.15561/18189172.2017.0203

Ivashchenko, O.V. (2016). Modelling of physical education students: Monograph. Kharkiv: OVS (in Ukrainian)

Acher, A., Arca, M., \& Sanmarti, N. (2007). Modeling as a teaching learning process for understanding materials: A case study in primary education. Science Education, 91(3), 398-418. https://doi.org/10.1002/sce.20196

Chatzipanteli, A., Digelidis, N., Karatzoglidis, C., \& Dean, R. (2016). A tactical-game approach and enhancement of metacognitive behaviour in elementary school students. Physical Education and Sport Pedagogy, 21(2),169-184. https:/doi.org/10.1080/17408989.2014.931366

Chernenko, S.O. (2015). Effectieness of junior form pupils' training of gymnastic exercises in different modes of their fulfillment. Pedagogics, Psychology, MedicalBiological Problems Of Physical Training And Sports, 19(8), 65-74. https://doi.org/10.15561/18189172.2015.0809

Correa, A. A., Grima, P., \& Tort-Martorell, X. (2009). Experimentation order with good properties for $2 \mathrm{k}$ factorial designs. Journal of Applied Statistics, 36(7), 743-754. https://doi.org/10.1080/02664760802499337

Correa, A. A., Grima, P., \& Tort-Martorell, X. (2012). Experimentation order in factorial designs: new findings. Journal of Applied Statistics, 39(7), 1577-1591. https://doi.org/10.1080/02664763.2012.661706

García-Moya, I., Moreno, C., \& Jiménez-Iglesias, A. (2012). Building a composite factorial score for the assessment of quality of parent-child relationships in adolescence. European Journal of Developmental Psychology, 10(5), 642-648. https://doi.org/10.1080/17405629.2012.707781

Kapkan, O.O. (2015). Features of 14-15 years' age boys' training to physical exercises. Pedagogics, Psychology, Medical-Biological Problems Of Physical Training And Sports, 19(9), 26-32.

https://doi.org/10.15561/18189172.2015.0904

Wang, A., Karns, J. T., \& Meredith, W. (2003). Motivation, Stress, Self-Control Ability, and Self-Control Behavior 
of Preschool Children in China. Journal of Research in Childhood Education, 17(2), 175-187.

https://doi.org/10.1080/02568540309595008

Wright Steven (1999). A compatative view of teaching practice in Physical Education. International Sports Studies, 21(1), 55-68.

Samuel, R. D., Zavdy, O., Levav, M., Reuveny, R., Katz, U., \& Dubnov-Raz, G. (2017). The Effects of Maximal Intensity Exercise on Cognitive Performance in Children. Journal of Human Kinetics, 57(1), 85-96. https://doi.org/10.1515/hukin-2017-0050

Khudolii, O. M., \& Iermakov, S. S. (2011). Regularities of the learning process of young gymnasts. Teoriâ ta Metodika Fizičnogo Vihovannâ, 0(5), 3-18, 35-41. (in Ukrainian) https://doi.org/10.17309/tmfv.2011.5.707
Cantell, M. H., Smyth, M. M., \& Ahonen, T. P. (2003). Two distinct pathways for developmental coordination disorder: Persistence and resolution. Human Movement Science, 22(4-5), 413-431. https://doi.org/10.1016/j.humov.2003.09.002

Donovan, C. B., Mercier, K., \& Phillips, S. R. (2015). Investigating Attitudes Toward Physical Education: Validation Across Two Instruments. Measurement in Physical Education and Exercise Science, 19(2), 91-98. https://doi.org/10.1080/1091367X.2015.1012511

Herrmann, C., Gerlach, E., \& Seelig, H. (2016). Basic motor competences in primary school. Rationale, assessment and empirical testing of a measurement instrument. German Journal of Exercise and Sport Research, 46(2), 60-73. https://doi.org/10.1007/s12662-015-0378-8

\title{
РОЗПІЗНАННЯ ОБРАЗІВ: РЕЖИМИ ВИКОНАННЯ ФІЗИЧНИХ ВПРАВ У ПРОЦЕСІ ФОРМУВАННЯ РУХОВИХ НАВИЧОК У ДІВЧАТ 14 РОКІВ
}

\author{
Капкан O.O. ${ }^{1}$, Худолій О.М. ${ }^{2}$, Бартік П. ${ }^{3}$ \\ ${ }^{1}$ Донбаська національна академія будівництва і архітектури \\ ${ }^{2}$ Харківський національний педагогічний університет імені Г.С. Сковороди \\ ${ }^{3}$ Університет Матея Беля
}

Реферат. Стаття: 8 с., 10 табл., рис. 1, 21 джерело.

Мета дослідження - визначити режими виконання фізичних вправ у процесі формування рухових навичок у дівчат 14 років.

Матеріал і методи. У дослідженні прийняли участь 40 дівчат 14 років. Для вирішення поставлених завдань були використані методи дослідження: вивчення та аналіз науково-методичної літератури; педагогічне спостереження, хронометраж навчальних завдань; педагогічний експеримент, методи математичної статистики, методи математичного планування експерименту, дискримінантний аналіз.

Результати дослідження. Перша канонічна функція пояснює варіацію результатів на 73,3\%, друга функція - на 21,6\%, що свідчить про їх високу інформативність $\left(r_{1}=0,898 ; r_{2}=0,743\right)$. Аналіз канонічних функцій вказує на статистичну значущість першої і другої канонічної функції $\left(\lambda_{1}=, 067 ; p_{1}=0,001\right.$; $\left.\lambda_{2}=0,346 ; p_{2}=0,001\right)$. Перша і друга функція мають високу дискримінантну здатність і значення в інтерпретації відносно генеральної сукупності. 3 найбільшим вкладом в першу канонічну функцію входять: кількість повторень на оволодіння першої та четвер- тої серії навчальних завдань, що свідчить про вплив вправ для розвитку рухових здібностей та навчання умінню управляти рухами за часом і м'язовими зусиллями на ефективність навчання стійки силою на голові і руках. 3 найбільшим вкладом в другу канонічну функцію входить: кількість повторень на оволодіння другої і третьої серії навчальних завдань, що свідчить про вплив вихідних і кінцевих положень та дій без яких неможливо виконати вправу на ефективність навчання стійки силою на голові і руках.

Висновки. Структурні коефіцієнти дискримінантної функції вказують, що ефективність програми навчання визначається підбором серій навчальних завдань і режимом їх виконання. Для вибору найбільш раціонального режиму виконання вправ серії завдань у процесі навчання стійці силою на голові і руках дівчат 14 років може бути використана перша дискримінантна функція з акцентом на найбільш інформативні змінні.

Ключові слова: дискримінантний аналіз, серії навчальних завдань, програмоване навчання, дівчата. 


\title{
РАСПОЗНАВАНИЕ ОБРАЗОВ: РЕЖИМЫ ВЫПОЛНЕНИЯ ФИЗИЧЕСКИХ УПРАЖНЕНИЙ В ПРОЦЕССЕ ФОРМИРОВАНИЯ ДВИГАТЕЛЬНЫХ НАВЫКОВ У ДЕВОЧЕК 14 ЛЕТ
}

\author{
Капкан Е.А. ${ }^{1}$, Худолей О.Н. ${ }^{2}$, Бартик П. ${ }^{3}$ \\ ${ }^{1}$ Донбасская государственная машиностроительная академия \\ ${ }^{2}$ Харьковский национальный педагогический университет имени Г. С. Сковороды \\ ${ }^{3}$ Университет Матея Беля
}

Реферат. Статья 8 с., 10 табл., Рис. 1, 21 источник.

Цель исследования - определить режимы выполнения физических упражнений в процессе формирования двигательных навыков у девочек 14 лет.

Материал и методы. В исследовании приняли участие 40 девочек 14 лет. Для решения поставленных задач были использованы методы исследования: изучение и анализ научно-методической литературы; педагогическое наблюдение, хронометраж учебных задач; педагогический эксперимент, методы математической статистики, методы математического планирования эксперимента, дискриминантный анализ.

Результаты исследования. Первая каноническая функция объясняет вариацию результатов на $73,3 \%$, вторая функция - на $21,6 \%$, что свидетельствует об их высокой информативности $\left(r_{1}=0,898\right.$; $\left.r_{2}=0,743\right)$. Анализ канонических функций указывает на статистическую значимость первой и второй канонической функции $\left(\lambda_{1}=, 067 ; p_{1}=0,001 ; \lambda_{2}=0,346\right.$; $\left.p_{2}=0,001\right)$. Первая и вторая функции имеют высокую дискриминантную способность и значение в интерпретации относительно генеральной совокупности. С наибольшим вкладом в первую каноническую функцию входят: количество повторений на овладение первой и четвертой сериями учебных заданий, что свидетельствует о влиянии упражнений на развитие двигательных способностей и обучение умению управлять движениями во времени и мышечными усилиями на эффективность обучения стойки силой на голове и руках. С наибольшим вкладом во вторую каноническую функцию входит: количество повторений на овладение второй и третьей сериями учебных заданий, что свидетельствует о влиянии исходных и конечных положений и действий без которых невозможно выполнить упражнение на эффективность обучения стойки силой на голове и руках.

Выводы. Структурные коэффициенты дискриминантной функции указывают, что эффективность программы обучения определяется подбором серий учебных заданий и режимом их выполнения. Для выбора наиболее рационального режима выполнения упражнений серии заданий в процессе обучения стойке силой на голове и руках девочек 14 лет может быть использована первая дискриминантная функция с акцентом на наиболее информативные переменные.

Ключевые слова: дискриминантный анализ, серии учебных заданий, программированное обучение, девочки.

\section{Information about the authors:}

Kapkan O.O.: ekapkan@gmail.com; http://org/0000-0003-4320-4276; Department of Physical Education Donbas National Academy of Civil Engineering and Architecture; Nebesnoi Sotni St, 14, Kramatorsk, 84333, Ukraine.

Khudolii O.M.: khudolii.oleg@gmail.com; http://orcid.org/0000-0002-5605-9939; Department of Theory and Methodology of Physical Education, Health and Medical Physical Culture, H. S. Skovoroda Kharkiv National Pedagogical University, Alchevskikh St, 29, Kharkiv, 61002, Ukraine.

Bartík P.: pavol.bartik@umb.sk; https://orcid.org/0000-0002-2087-7876; Department of Physical Education and Sports, Matej Bel University. Tajovského 40, 97401 Banská Bystrica, Slovakia.

Cite this article as: Kapkan, O.O., Khudolii, O.M., \& Bartík, P. (2018). Pattern Recognition: Physical Exercises Modes During Motor Skills Development in Girls Aged 14. Teorîa ta Metodika Fizičnogo Vihovannâ, 18(4), $167-174$.

https://doi.org/10.17309/tmfv.2018.4.02

Received: 15.11.2018. Accepted: 20.12.2018. Published: 25.12.2018 